\title{
The "Aum Incident" as a Catalyst for Societal Critique: An Analysis of Letters to the Editor of Asahi Shinbun on Aum Shinrikyō
}

\author{
Patricia Sophie Mayer \\ iD https://orcid.org/0000-0003-0832-781X
}

\begin{abstract}
This article analyses the discussion of Aum Shinrikyo in letters to the editor of one of the major Japanese newspapers, Asahi Shinbun, through the method of qualitative content analysis. The examination focuses on two aspects of the letters in order to uncover how Aum is understood and localised in a bigger context: first, how Aum itself is discussed, and second, what topics are brought up in relation to the group. The analysis reveals that Aum was rarely referred to as a cult or a false religion, but more often merely as a religion, which is subsequently associated with negative notions. The majority of letters, however, did not specify the nature of Aum at all. This is congruent with the topics covered in the letters, since the content of a large portion of them is not concerned with Aum directly but with a more abstract critique of society and authorities. Letters to the editor of Asahi Shinbun for a large part do not make use of sensationalist wording, all the while expressing a critical stance towards the movement, and additionally they focus on a critique of the dealings with Aum prior to and after the subway attack in 1995.
\end{abstract}

Keywords: Aum Shinrikyō, cult debate, media, content analysis, discourse of religion

Mayer, Patricia Sophie. 2021. "The "Aum Incident" as a Catalyst for Societal Critique: An Analysis of Letters to the Editor of Asahi Shinbun

\section{Ssciendo} on Aum Shinrikyō." Vienna Journal of East Asian Studies, 13, pp. 177209.

https://doi.org/10.2478/vjeas-2021-0006

Submitted: 08.04.2021, accepted: 25.04.2021 


\section{Introduction}

According to several polls, one of the events of the Heisei era (Heisei jidai 平成時 代) - which spanned from January 8, 1989 to April 30, 2019-with the biggest societal impact appears to be the sarin gas attack on the Tōkyō subway on March 20, 1995, carried out by members of the new religious movement ${ }^{1}$ Aum Shinrikyō (Ōmu Shinrikyō オウム真理教) (Keishichō 2016; J-town.net 2018; Nifty News 2019). Formed in 1984 as Aum no Kai オウムの会 and later Aum Shinsen no Kai オウム神仙の会 by Asahara Shōkō 麻原彰晃 (1955-2018), the group began as a kunḍalinī yoga circle influenced by selected Buddhist concepts (Baffelli 2018: 196). In the first years after its founding the group faced public criticism from relatives of members who had strictly rejected their former lives and lived in isolation from them; ${ }^{2}$ this was one of the reasons its first application to receive status as a religious corporation was rejected. Still, the mainstream attitude towards the group was overall indifferent and Asahara's second appeal for legal status - accompanied by his public complaints against the initial rejection of what was now called Aum Shinrikyō - was approved in the first year of the Heisei era (1989), making it a legally acknowledged religious cooperation (Reader 1996: 36-37; Watanabe 1997: 34).

Following its recognition as a religious corporation, Aum Shinrikyō (henceforth Aum) would find itself in the media spotlight several times until the attack in 1995. For example, the weekly magazine Sunday Mainichi サンデー毎日 was quick to publish a critical series on Aum in October 1989 bringing up, among other things, the aforementioned separation of believers from their friends and relatives and the practice of blood initiation. ${ }^{3}$ Reactions to the series included roughly 200 letters to the magazine containing complaints against Aum from relatives and former members, as well as the forming of the group Aum Shinrikyō Higaisha no Kai 才ウム真理教被害 者の会 (Aum Shinrikyō Victim Association) for said individuals (Reader 1996: 38). One year later, Asahara decided to pursue his political ambitions by founding a party (Aum Shinritō オウム真理党) and running for the 1990 general election. Their peculiar campaigning style succeeded in garnering media attention, albeit ridicule, since it

\footnotetext{
${ }^{1}$ One scholarly categorisation of Japanese new religious movements would locate Aum in that of "new new religions," denoting groups that were founded after the 1973 oil-shock (Astley 2006: 9596). The term "new new religious movement" should therefore be understood to differ from the shorter "new religious movement" (NRM) mostly concerning temporal positioning (Winter 2018: 25). Since the former is not universally accepted, however, the latter is used in this article.

${ }^{2}$ These believers are referred to as shukkesha 出家者, a term derived from Buddhism to denote an individual who has left their home and renounced the world. In 1995, more than one thousand members of Aum lived as shukkesha in communes (Baffelli 2018: 193).

${ }^{3}$ Aum made claims that, according to the results of a laboratory test that had never actually been conducted, Asahara's blood contained special DNA that could aid the aspirants' spiritual development when consumed during initiation (Reader 1996: 38).
} 
consisted mainly of the public chanting of Asahara's name and wearing masks of either his face or of that of an elephant. Unsurprisingly, the Aum Shinrito suffered a devastating loss with not a single candidate being voted to the Diet (Hardacre 2007: 187; Reader 1996: 43-44). A retreat to Ishigaki-jima 石垣島, Okinawa 沖縄, with around a thousand members had to be cancelled because the media, anticipating that Asahara might plan to replicate the 1978 Jonestown massacre, overflooded the island (Hardacre 2007: 187). The next year (1991) Aum could somewhat rehabilitate its public image by appearing on a TV programme together with members of the new religious movement Kōfuku no Kagaku 幸福の科学. In the four-hour-long live broadcast, Aum members could show that they were more informed about Buddhism than those of Kōfuku no Kagaku (Asahara was present; Kōfuku no Kagaku's president Ōkawa Ryūhō 大川隆法 [b. 1956] was not), resulting in positive evaluations by some scholars of religion (Wilkinson 2009: 154-155; Watanabe 1997: 37-38). For many years Aum and the media would clash when the group was involved in conflicts concerning the residency of its members in small towns in rural areas, for example in the villages of Namino 波野 (Kumamoto 熊本 Prefecture) and Kamikuishiki 上九一色 (Yamanashi 山梨 Prefecture). Often times the sellers were not aware that a religious organisation was buying their land, and the subsequent migration of large numbers of Aum members was conceived as a threat to the societal balance of the small communities. The media would take the side of the town residents in the disputes and criticise Aum for its vigorous pressing for the right to purchase large amounts of land, calling into question whether a legitimate religion could be so harsh in their approach to the matter, taking legal action against residents as well as readily counter-critiquing the media. When the purchase of land in Matsumoto 松本 did not go through as expected, the group reacted with a sarin gas attack in 1994, injuring dozens of people and killing seven (Hardacre 2007: 188-189; Reader 1996: 46-49; Wilkinson 2009: 63). ${ }^{4}$

When the Tōkyō Metropolitan Police started to look more closely into Aum and the group leadership was informed via espionage that raids on Aum facilities were planned, the decision was made to attack the police department in the government district in Kasumigaseki 霞ヶ関. On March 20, 1995, Aum committed the attack on the Tōkyō subway, during which five high-ranking members chosen by Asahara brought bags filled with sarin on trains and punctured them to spread the gas. Luckily, the sarin was poorly made and its smell alarmed the passengers immediately, so that the number of people killed remained relatively low at twelve; however, thousands were injured and required medical help (Wilkinson 2009: 74-81). Two days later, the police heavily raided Aum buildings and the media drastically increased coverage of

\footnotetext{
${ }^{4}$ However, Aum members were not treated as suspects in the case for years and investigations only started after the subway attack. The media played a strong role in this, supporting the police's treatment of one of the victims, Matsumoto local Kōno Yoshiyuki 河野義行 (b. 1950), as the primary suspect (Wilkinson 2009: 71-73).
} 
the affair as well as the movement. Several more attacks were conducted by members of Aum, even after Asahara's arrest in May (Reader 1996: 87). His trial commenced a year after the attack, in April 1996, being uncooperative and showing no signs of remorse in the process. In 1999, the group received a note to stop using its name and, roughly coinciding with the release of Aum-spokesperson Jōyū Fumihiro 上祐文博 (b. 1962), Aum was renamed "Aleph" (Arefu アレフ). Asahara received the death sentence after approximately eight years of trials in 2004, and following appeals from his lawyers and family, the sentence was finalised by the Supreme Court in 2006. The trials of other Aum members (189 in total) started as early as 1995 and resulted in eighty prison sentences, five life-long sentences, and thirteen death sentences. In 2011 and 2012, three individuals who had been wanted either turned themselves in or were arrested and their trials were completed in 2016 (Baffelli 2018: 203-204). After around twelve years of imprisonment, Asahara was executed by hanging on July 6, 2018, together with other convicted members of the group (Yoshida and Murakami 2018).

Important points in the history of the group itself roughly coincide with the Heisei timeframe, with Aum being legally acknowledged as a religious corporation in August of the first year of Heisei (1989) and - after numerous conflicts, incidents, trials, and sentences - its founder Asahara Shōkō being executed in July 2018, less than a year before the era came to a close. Thus, it can be said that the two are closely temporally intertwined and the case of Aum kept being brought back to the surface of the minds of Japanese people repeatedly during the whole era, making a deep impression as the above-mentioned poll results suggest.

\section{Aum and the Media}

New religious movements (shinshūkyo 新宗教) in Japan have been the focus of public criticism from early on. Levi McLaughlin (2012: 61) suggests that one could go as far as to say that the very notion has come to signify something that deviates from the standard, hypothetical proper religion. In the Meiji period (Meiji jidai 明治時代, 1868-1912), the development of print media was actively supported as well as controlled by the government. Consequently, anything that could potentially pose a threat to the established order was prone to criticism, and new religious movements that were suspected of this were confronted with considerable condemnation that was echoed in the public image of those groups. The media's assumed role of a monitoring body of societal cohesion and the calling out of potentially subversive groups continued after World War II (Baffelli 2016: 17-19). For a large part even in the modern day there appears to be, as Helen Hardacre (2007: 142) puts it, "an informal taboo on reporting good news" when it comes to religious groups, which makes it difficult for consumers of Japanese media to attain a positive image of them (ibid.: 143). 
New religious movements (henceforth NRMs) have for a long time been eyed somewhat suspiciously, and while not necessarily bringing new aspects into the discussion on NRMs, no group has had the impact that Aum Shinrikyō had in strengthening the notion of NRMs as potentially threatening to society, with some religious groups being associated with the terms "dangerous" (abunai 危ない) and "cult" (karuto カルト) more readily than they already were before (McLaughlin 2012: 71; Watanabe 1997: 32; Winter 2018: 26). As shown above, Aum had repeatedly been in the media's spotlight before March 1995, and while coverage was not exclusively negative (Baffelli 2016: 26), some of it had already been negatively connotated. The subway attack and subsequent events were heavily covered in the media, with some broadcasting companies dedicating up to fifty hours weekly (Watanabe 1997: 39). While Ian Reader (1996: 108) refers to an "Aum industry" that developed in the media following the attack, Hardacre (2007: 175) calls the extensive coverage a "major obsession."

Some scholars were critical of negative representations of NRMs in the media, arguing that their only aim was to create sensational stories that would gain reader interests rather than spreading information regarding religious groups. Some criticised the media's conduct even after the attack. One of the scholarly critics, Shimada Hiromi 島田裕巳 (b. 1953), who had spoken favourably of Aum several times before the attack and subsequently stepped down from his tenured position at Japan Women's University 日本女子大学 when public criticism grew too strong after the attack, contrasted the media's and scholars' roles by asserting that while the mass media were after sensational stories, scholars were interested in the groups' criticisms of society (Wilkinson 2009: 122; Watanabe 1997: 46). In the case of the conflicts Aum had with several towns' residents over the purchasing of large portions of land, for example, some intellectuals criticised the residents' movements against the group (Watanabe 1997: 36), positioning themselves in direct opposition to the media as outlined in the previous section. However, their voices completely lost their momentum after the subway attack, through which Aum proved to be as anti-social and dangerous as the media and anti-cult activists had often portrayed it. The public expected scholars of religion to be able to identify and warn society of dangerous movements. After these expectations were not met, scholars lost authority as well as credibility-in the case of Shimada, going as far as being openly criticised on TV shows he appeared (Watanabe 1997: 46-48; Reader 1996: 109-110). After scholars of religion had lost their authority in assessing NRMs, their place was taken by other groups - journalists and anti-cult activists - who, even before the attack in Tōkyō, had openly criticised Aum and warned of the group's inherent dangerousness. They turned out to be correct when members of the group were openly treated as main suspects in the subway attack from the beginning. Thus, the credibility that was taken from the scholars who had turned out to be wrong about Aum's violent potential was transferred to the "new 
experts," as Gregory Wilkinson calls them. They offered an alternative to the scholarly critique of Japanese society by arguing that the group's leadership used mind control to lead its adherents to commit crimes (Wilkinson 2009: 120-131). Several newspapers were quick to publish books on Aum and the subway attack consisting of collected articles in the same year, among them Asahi Shinbun 朝日新聞 (Watanabe 1997: 39). Also in the same year, Asahi Shinbun published a Japanese translation of the 1988 anti-cult book Cults: What Parents Should Know (Rosu and Rangōne 1995). ${ }^{5}$ The book Combatting Cult Mind Control (1988) by Steven Hassan (b. 1954), a former Unification Movement member, was translated into Japanese by Asami Sadao 浅見 定雄 (b. 1931) (Hassan 1993). Both were influential in establishing the concepts of "cults" and "mind control" (maindo kontorōru マインドコントロール) in the Japanese discourse, also by appearing on television (Watanabe 1997: 40-41). ${ }^{6}$ Martin Repp (1997: 68-70) strongly disapproves of the Japanese media's approach to the affair and its strong influence on the public; he sees in the media an irrational hunger for sensationalism, firing up "hysteria" as he puts it, among people and making rational engagement with the matter virtually impossible.

Members of several NRMs had been portrayed as threatening or peculiar in the past, and the Aum affair was instrumentalised by the media to increase their audience (Baffelli 2016: 14-15). Given these circumstances, after the subway attack, journalists also focused on other NRMs, their alleged similarities to Aum, and therefore their harmful potential (ibid.: 25). One such group was the NRM Chino Shōhō 千乃正法, which reminded the public of Aum due to its members' behaviour and expectations of the world's end. In 2003, the research sub-group of the movement, Panawave Laboratory (Panawēbu Kenkyūjo パナウェーブ研究所), received media attention when it became involved with a seal, more specifically an arctic seal that had lost its way and got stranded in a river in Japan in 2002. Named Tama-chan after the Tōkyō river

\footnotetext{
${ }^{5}$ One of the authors, Michael D. Langone (b. 1947), is a psychologist and executive director of the International Cultic Studies Association (ICSA), founded in 1979 as American Family Foundation (AFF). On its website, the group defines itself as "a global network of people concerned about psychological manipulation and abuse in cultic and other high-control environments" (ICSA 2021).

${ }^{6}$ Both influential books are in ways connected to the Unification Movement. While Hassan was a member himself, the ICSA was founded by a member's concerned parents. The movement has repeatedly received negative media attention in and outside of Japan (Pokorny 2018: 322; cf. Introvigne 2000). As early as the 1960 s, Japanese media reported on the group in connection to university students dropping out after they had joined. A series of lawsuits involving former members accusing the movement of having robbed them of their youth is commonly called "Give back my youth lawsuits” (seishun o kaese soshō 青春を返せ訴訟) (Sakurai 2002: 70-71). Furthermore, the Unification Movement was involved in a lawsuit in 2008 with a former member over having been pressured to make large donations, which was settled with a payment of 230 million Yen (Wilkinson 2009: 149).

${ }^{7}$ For a short history of the movement and more on the affair connecting it to Aum, see Dorman 2005.
} 
Tama-gawa 多摩川, the animal quickly rose to fame and became highly popular among Japanese people. One group eager to help the animal was associated with Panawave Laboratory, which led the media to stumble upon the group's idiosyncratically shaped and disaster-proof buildings intended to protect its members and Tama-chan. The group had planned to return the seal to its natural living environment after natural catastrophes the group expected to occur were over. Efforts to associate Panawave Laboratory with Aum were made by using terms coined by the latter in connection to the group. Media attention spread to the movement's founder, as well as to its white vans and the members' white clothing, which made comparisons to Aum easy. Panawave and Aum were covered in the same stories, eventually leading to the involvement of the National Police Force, which in turn produced fear among the public of the possibility of yet another potentially dangerous group (cf. Dorman 2005; Winter 2018: 27; Wilkinson 2009: 151-152, 157-166).

Another group discussed in connection to Aum was the NRM Sōka Gakkai 創価 学会. In the wake of the subway attack, political measures presumably taken only against Aum were actually also used against Sōka Gakkai and its political party, the Kōmeitō 公明党. Those political and journalistic groups that greatly impacted the discourse concerning Aum adopted the same rhetoric they had applied to Sōka Gakkai, with Aum serving as a motive in further critiquing Sōka Gakkai. Both being categorised as NRMs, politics and media commonly conflated the two. One example is the use of subliminal cuts in visual material: the media company TBS (Tokyo Broadcasting System) cut pictures of Asahara and Sōka Gakkai's leader, Ikeda Daisaku 池田大 作 (b. 1928), into reports on Aum facilities for extremely short periods of time, hence the subtlety of the technique. ${ }^{8}$ While the effectiveness of subliminal cuts is not universally accepted, more obvious conflations did have an effect on the public image of Sōka Gakkai and resulted in an association of the two groups in the discourse (cf. McLaughlin 2012).

With the concepts of "cults" (in the case of Aum, a "doomsday cult" as coined by the press [Reader 1996: 43]) and "brainwashing" firmly established in the post-Aum discourse, the media were eager to draw the image that there is "only a thin line" between "cults" and "religion" (Hardacre 2003: 153), and Aum clearly was not a proper religion according to journalists (Reader 1996: 94). At the beginning of the millennium, Hardacre (2003: 153) wrote that "the public sphere is now thoroughly poisoned against religion," and more recently Erica Baffelli (2016: 28) asserted that NRMs "have been (and still are) often represented as 'problematic'."

\footnotetext{
${ }^{8}$ There is no universal acceptance that subliminal cuts have an impact on viewers; on the contrary, one could speak of an almost universal negation of any effect on the audience. In any way, the frequency of subliminal images used by TBS would have been too low to exert any influence (Hardacre 2007: 198) and the practice rather functions as an example of the company's attitude towards religious groups.
} 
The sociologist of religion Eileen Barker has critiqued media attitudes towards NRMs and sought to understand its conduct by taking the conditions of production into consideration. The main objective of media outlets is maintaining and ideally gaining audience and, in an effort to do so, finding stories that will generate as much attention as possible. Since everyday life in NRMs is not regarded sensational enough, efforts to present spicier stories are made. Headlines need to garner interest and, if possible, cause an emotional response. In addition, content creators work on strict time schedules, influencing the way they research for their stories since they require easily accessible information. Furthermore, they are also restricted in the space (or time) they can devote to their content, so that only so much informational value can be put into their work. Another problem is that journalists appear to be rather reluctant to bring members of the religious groups themselves into the conversation. These circumstances lead to sensationalist and unbalanced reports that are often found in mass media. However, due to their high social significance, the media's depictions of NRMs are both widespread and highly influential, all the while proving to be difficult to rectify (Barker 1995: 299-300).

Whereas the role of the media in the Aum affair has been prominently featured in scholarly publications, the voices of those who consume the media have not been equally studied. In her 2007 article, Hardacre does feature some letters to the editor of Asahi Shinbun anecdotally, but there is no systematic examination of them. With the media landscape being rather unfavourable for NRMs as outlined above, the question arises how these depictions resonated with the (usually) receiving side, the media consumers. Those readers are enabled to become writers, producers of media content in the newspaper sections dedicated to letters to the editor.

\section{Letters to the Editor}

Following a sociology of knowledge approach, Barker differentiates between primary and secondary constructions of reality. Whereas in the case of primary constructions of NRMs the members themselves are the (unconscious) driving force through their interactions between themselves and to some extent outsiders, secondary constructions are consciously produced by outsiders as well as members in public contexts (Barker 1995: 288). Thus, this analysis will focus on secondary constructions of Aum Shinrikyō produced in letters to the editor of Asahi Shinbun in the Heisei era. ${ }^{9}$ Correspondingly, the initial timeframe for the corpus was set in spanning the entire era. The

${ }^{9}$ Asahi Shinbun is one of the largest national daily newspapers in Japan, second only to Yomiuri Shinbun 読売新聞 in terms of circulation, with 5.16 million copies of its morning edition in 2020. Its readership consists primarily of individuals in their forties to sixties, and according to the company's own data, $45.7 \%$ of its readership have at least one university degree (Kōkoku Asahi 2021: 7). In terms of political stance, it is generally regarded to be left-leaning. 
query employed to find relevant letters to the editor in the paper's database Kikuzo II Bijuaru 聞蔵IIビジュアル was “オウム\& (声)” (Ōmu\&(koe)). The reason for searching for only Ōmu オウム instead of the full name Ōmu Shinrikyō オウム真理教 is that the group is often referred to using abbreviations, such as Ōmu or sometimes Ōmukyō オウム教. Consequently, letters not featuring the full name of the movement would not have appeared in the search results. By choosing the lowest common denominator, the efficiency of the query could be maximised. The construction "(koe)" (声) with full-width brackets in headlines is used to demarcate letters to the editor in Asahi Shinbun. By connecting the two parts with an ampersand, the command was given to the engine to search for texts containing both terms in their titles and/or texts. However, my search did not bring up any results prior to the subway attack, with letters meeting the search requirements only having been published from March 28, 1995 onwards, that is, eight days after the attack. ${ }^{10}$ Consequently, the publication dates of the analysed letters span from March 28, 1995 to April 30, 2019. The initial search returned a total of 229 results, of which eleven were not related to Aum in any way or were duplicates published a second time in different paper editions. Removing those from the corpus, 218 letters remained for analysis. Half of the letters were published within the first two years following the attack, with January 6, 1997 being the publication date of letter no. 109. This indicates that interest in the topic was extremely high in the months after the attack, subsequently decreasing but nevertheless remaining present until the end of the Heisei era.

The media researcher Karin Wahl-Jorgensen identified four unwritten rules by which editorial teams of newspapers select readers' letters for publication. (1) Relevance of topic is one of the criteria looked for, meaning that letters concerned with current issues are more likely to be chosen. At the same time, they should ideally be (2) entertaining as well as (3) short and to the point. Lastly, the rule of (4) authority entails the fact that letters by authors with solid outsider expertise on the topic they are writing about and the skill to do so in an eloquent manner are favoured by editors. As a consequence, letters by older individuals with a higher degree of education have better chances to be published (Wahl-Jorgensen 2002: 73-78). The growing importance of the internet as a medium with a virtually non-existent barrier in terms of who can contribute to discussions during the examined timeframe may be another reason for less contributions from younger people.

The demographics of letter authors in the corpus examined in this article seem to widely confirm this: the largest age group among the authors of the letters is comprised by individuals in their sixties $(21.5 \%, 47$ total), closely followed by those in their forties $(21.1 \%, 46$ total $)$ and fifties $(17.4 \%, 38$ total). Together, these age groups

\footnotetext{
${ }^{10}$ The full text database contains all articles published in Asahi Shinbun from 1985 onwards, including all prefectures and editions except Okinawa, and enables the user to search the entire texts. Therefore, letters to the editor of the entire Heisei era are available.
} 
account for $60 \%$ of the letters. ${ }^{11}$ Since members of the workforce in their forties to sixties are usually close to or at the highest points in their careers (or just retired), one can assume relative economic wellbeing for most of them, which enables them to take the time to write and send contributions to newspapers; this is also a common characteristic of letter authors that Wahl-Jorgensen points out (2002: 77). An examination of the information given regarding the jobs of the respective letter writers confirms this: the vast majority of them work in so-called white-collar jobs, for example as general company employees (15.14\%, 33 total), teaching staff at various educational institutions $(7.79 \%, 17$ total), in mental as well as physical health care $(6.42 \%, 14$ total), as freelancers $(5.5 \%, 12$ total), in various leading or managing positions $(5.05 \%$, 11 total), as researchers $(2.75 \%, 6$ total $)$, in the media $(2.29 \%, 5$ total $)$, as lawyers $(1.38 \%, 3$ total), or publishers (1.38\%, 3 total). Authors currently in school or higher education penned further $10.55 \%$ (23 total) of the letters. Another noteworthy group of authors is that of artists $(1.83 \%, 4$ total). Housewives were among the largest groups with $10.55 \%$, or 23 authored letters. While this is no indicator of the education of the authors themselves, it suggests the existence of a partner or spouse who is financially stable enough to allow for them to stay at home. The largest group of authors is jobless (mushoku 無職) with $18.35 \%$ (40 total). This, however, does not necessarily mean they are unemployed; the term is also used as an indicator for retirement by Asahi Shinbun. Since $90 \%$ (36 total) of the authors characterised as mushoku are sixty years of age or older, in most cases retirement is the more probable case. All taken together, these author groups alone compose around $88.98 \%$ of the letters. Therefore, it can be concluded that the secondary constructions examined in this article should be regarded as mainly middle-class and elite discourses - in accordance with the aforementioned readership statistics of Asahi Shinbun - and are not representative of the views of Japanese society as a whole. Although the examined letters to the editor should thus not be regarded a faithful reproduction of the vox populi functioning according to entirely democratic principles, they are nevertheless a site for public discussion by people who otherwise do not get extensive opportunities to voice their opinions in the media and be heard by a wide audience (Wahl-Jorgensen 2002: 70).

The editors that select and edit articles for publication play a central role in the shaping of the letters section (Wahl-Jorgensen 2007: 5). Therefore, these sections should be understood as a forum for public discourse with limitations that should at all times be kept in mind (ibid.: 71). The Asahi Shinbun publishes five to ten letters to the editor every day on the same page as the editorials, giving them thus a rather prominent space. The length of the letters varies from a minimum of 300 to a maximum of 500 characters, making them a quick and therefore inviting read (cf. Shioya 2017).

\footnotetext{
${ }^{11}$ Contributors in their teenage years penned $2.8 \%$, in their twenties $10.6 \%$, and in their thirties $14.2 \%$ of the examined letters. Letters by authors in their seventies amount to $9.6 \%$, in their eighties $2.3 \%$, and the single one by an author in their nineties to roughly $0.5 \%$.
} 


\section{Analysis}

The following twofold analysis is concerned with 1) how Aum is defined by authors of letters to the editor of Asahi Shinbun, and 2) what topics are brought up in relation to the group, with the aim to uncover how Aum is understood and localised in a bigger context.

\section{The Definition of Aum}

Definitions of Aum in the letters can be subsumed under five categories: 1) cult; 2) false or improper religion; 3) explicit religion; 4) implicit religion; and 5) no statement. The categories vary in "tensity," with 1) being the strongest and 5) the weakest. This means, for example, a letter containing keywords belonging to group 2) and 3) was added to group 2). Considering the heavy usage of the terms "cult" and "mind control" in Japanese media discourse concerning Aum following the subway attack as outlined above, it is surprising that the words karuto カルト and mind control (maindo kontorōru マインドコントロール or マインド・コントロール) as well as brainwashing (sen'nō 洗脳) are rarely used in the letters to the editor. In fact, they could only be found linked to Aum in ten cases (six containing "cult" [2.75\%] and four [1.84\%] a variation of "mind control"), accounting for merely $4.59 \%$ of all letters taken together. In some cases, terms for mind control and brainwashing were used in the letters but not in connection to Aum. The four letters that fall into this category use these words to describe the educational system or the government during the war. The author of one letter asserts that the media claim Aum employed techniques of mind control but did not comment on whether they agree with that. This means that of eight letters referring to a form of mind control, only $50 \%$ attribute the practice to Aum directly. Thus, it can be argued that although the two concepts were readily employed in media productions - as mentioned above, the Asahi Shinbun itself published books with these words in the title - and therefore writers should not be too hesitant to use them in their own submissions, the concepts did not appear in their writings (if they were indeed stuck in their minds at all).

Another very small portion of letters defined Aum as "false or improper religion." In total, nine letters fall into this category, amounting to solely $4.13 \%$ of all letters examined. The criteria for a classification in this category were expressions denoting only pretending to be a religion or hiding behind the concept of religion. For example, shūkyōo kakuremino 宗教を隠れみの (religion as a guise), shūkyō no men o kabutta 宗教の面をかぶった (put on religion as a mask), shūkyo modoki 宗教もどき (pseudoreligion) - putting religion, religious group, etc. in quotation marks while not being a quote or a discussion of a concept, adding the term jisho 自称 (self-proclaimed) to them, or a simple negation in the form de wa nai ではない (is not). Another strategy to denote Aum as improper religion that could be found in the letters was contrasting 
the group's actions to the true nature of religion (honrai 本来), the should-be, which is characterised positively. This will be discussed further in the second part of the article.

Letters categorising Aum as a religion or religious group are significantly more in number than the previously described categories, which, in one way or another, attribute to Aum a deviant form of religion. While the latter make up $8.72 \%$ of all letters, the ones referring to the group as a religion make up $33.94 \%$ of the corpus. These were split up into two categories: firstly, those calling Aum a religion explicitly $(19.72 \%)$ and, secondly, those doing so in an implicit manner (14.22\%). Letters were added to the first category when they refer to Aum as a "religion" (shi $\bar{k} y \bar{o}$ 宗教) or “new religion” (shinshūkyō 新宗教), or, more commonly, a "religious group”/“religious organisation” (shūkyō dantai 宗教団体, shūkyō shūdan 宗教集団, or kyōdan 教団). Implicit labelling of Aum as a religion is accomplished in the letters by referring to Asahara as a "religious founder" (kyōso 教祖), "guru” (sonshi 尊師), or the “religious leader” (shūkyō shidō-sha 宗教指導者). Furthermore, Aum was implicitly referred to as a religion by calling its members "believers" (shinja 信者 or shinto 信 徒), “people with a religion," or “people with a religious belief” (shūkyō o motsu hito 宗教を持つ人, shinkōo motsu hitobito 信仰をもつ人々, or shinkō no hito 信仰の人). Lastly, the group was implicitly called a religion by attributing terms of religious activities or feelings to it or its members: for example, "religious activities" (shūkyō katsudō 宗教活動), “places of practice” (shugyō no ba 修行の場), “religious views" (shūkyō-kan 宗教観), “doctrine” (kyōgi 教義), “missionary work” (fukyō 布教), or

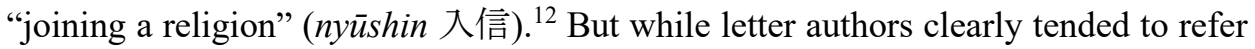
to Aum as a religion rather than a cult, the group - and, in some cases, religion in general-were not evaluated positively. This too will be examined more closely in part two of the article.

The decidedly biggest number of letters fall into the fifth category, namely, "no statement/neutral" with $57.34 \%$ of the corpus. In this context, "no statement" signifies letters that simply referred to Aum by a variation of its name and did not use any other term to refer to the group or its members. Neutral letters are those that also use other terms to refer to Aum or its members but do not clearly express whether Aum is a religion or not. For the group itself the keywords shüdan 集団, soshiki 組織, and dantai 団体 (all meaning group/organisation) were employed. Using these words to describe Aum does not negate the possibility that it is a religion or a cult, but the terms do not include this meaning. When discussing Aum's leadership and Asahara, the words kanbu 幹部 (leadership), daihyō 代表 (representative), and shidōsha 指導者 (leader) were used. Writing about members of the movement, letter authors in this

\footnotetext{
12 One may add that, depending on context, this vocabulary might also be used by authors who consider Aum a "false religion." However, there were no indications in the respective letters that this might be the case. Therefore, they were subsumed in this category.
} 
category chose member (menbā メンバー) or people (hitotachi 人たち) and, when referring to individuals on trials, also yoggisha 容疑者 (suspect), and after they had been convicted hanzaisha 犯罪者 (culprit). Again, it is important to note that the use of this vocabulary does not indicate that the authors did not consider Aum a religious movement or a cult. Rather, it can be understood as a sign that the authors did not care about or did not deem important to disclose how Aum should be defined or how they would define it. A closer examination of the letters' contents supports this hypothesis.

\section{Topics of Discussion}

Employing the multi-level abstraction method outlined by Philipp Mayring (2015), units of meaning were brought from individual statements or experiences to more general topics that were in turn validated against the corpus and corrected when necessary. These steps were repeated until no further refining was needed. In so doing, letter contents were identified and classified into nine highly abstracted categories through an inductive process. A tenth classification, called Mentions, was established to categorise letters in which Aum is only mentioned in a list of other things as an example, or in which Aum is only mentioned en passant and no other related statements are made. For the sake of receiving the most sensible results of the content analysis, the letters in the mentions group were excluded from the other categories and will be discussed separately.

\begin{tabular}{|l|l|}
\hline Themes & Count \\
\hline Aum & 46 \\
\hline Society & 41 \\
\hline Law & 41 \\
\hline Politics & 35 \\
\hline Media & 27 \\
\hline Mentions & 26 \\
\hline Education & 20 \\
\hline Executive & 16 \\
\hline Religion & 14 \\
\hline Trials & 14 \\
\hline
\end{tabular}

Table 1: Topics ranked by frequency of appearance

As one can observe, Aum has been established as its own category. Although it is the biggest one, it is nevertheless as such only by a relatively small difference. The need to make Aum its own category in letters to the editor arises from the fact that the mention of the group does not necessarily make the contents of the letter centre around Aum itself. Furthermore, some letters discuss more than one topic, explaining why there is a higher number of topics in the table than letters in the corpus. The categories 
identified will be discussed individually to illustrate what topics they comprise. Citations of letters will be followed by the date on which they were published according to the paper's online archive in brackets in the form $\mathrm{dd} / \mathrm{mm} / \mathrm{yy}$, and — if needed—with letters in alphabetical order corresponding to their position in the search result list to differentiate between letters published on the same day.

The letters categorised in the Mentions group were excluded for the sake of accuracy of the analysis of the other categories, since Aum in these letters is mentioned mainly in passing, among other things, as an example of negative events or problems in Japan $(05 / 05 / 95,24 / 05 / 95,21 / 06 / 95,12 / 08 / 95,19 / 12 / 95 a, 09 / 03 / 96,29 / 12 / 96$, $12 / 01 / 97,04 / 03 / 97,05 / 04 / 97,06 / 04 / 97,24 / 11 / 99,27 / 11 / 99,10 / 02 / 00,13 / 02 / 00)$, or as a negative event among others defining the Heisei era retrospectively $(21 / 04 / 19$, 30/04/19). In other instances, Aum was mentioned for context or as a rhetorical device with little to no significant connection to the main content of the letter $(13 / 06 / 95$, 22/06/95b, 27/10/95c, 26/02/97, 10/07/99, 16/11/03, 31/01/06, 06/07/09, 11/11/09).

\section{Aum}

The group became the most commonly appearing topic in letters featuring the term Aum. However, considering that the total number of letters is 218 , their number (fortysix) is rather small after all — roughly one fifth — keeping in mind that all letters contain the term. The aspects discussed are also rather limited, amounting to merely four: the group itself, the members, the founder, and the members' children.

The first aspect is the group itself. Aum is universally viewed negatively. From being “detestable" (憎い; 31/10/99b) to “dangerous" (危険; 02/07/99), their deeds, which make them resemble a “terrorist group” (テロリスト集団; 28/03/95b / テロ集団; 19/12/95b) to some authors, are unforgivable (許すことは出来ない; 04/07/00 / 許さ れるものではありません; 04/05/04). Aum has "strayed greatly from the true path of religion” (宗教本来の道から大きく逸脱し; 17/05/95) and has instead murdered people. For this reason, and given that the group did not issue public apologies for their crimes, authors are worried about the continued activities of the two follow-up groups Aleph (founded 2000) and Hikari no Wa 光の輪 (founded 2007), which are proselytising and attracting young members. Consequently, the groups should be watched closely $(30 / 11 / 11 ; 23 / 06 / 12 ; 14 / 07 / 18)$. Another reason for distrust is that fugitives did not readily turn themselves in (16/07/96). A common theme in the discussion of the group is the comparison to military groups, for example, in the way that "refusing to follow the leader's orders at the time may have been impossible for the defendants" (教祖の命令を拒否するのは、当時の被告らには不可能なことだったのだろう; 15/12/99). The believers' attitude towards the founder resembles those of children towards their fathers who committed atrocities during the war and are nevertheless viewed as good people (25/03/00). One author compared Aum to the Red Army, in 
that young people joined both movements to create a better society, and in both cases “it invited a horrible ending” (ひどい結末を招いてしまった; 02/12/11a).

The comparison of Aum to military structures also serves to question the degree of responsibility of the group's members. Whereas some authors believe that their “minds were being controlled” (マインドコントロールされた; 23/11/95), others argue it was not possible to resist the leader's orders, following the military analogy. However, authors are not in agreement on the responsibility of members. Having joined the movement voluntarily, responsibility follows. Members that stayed on even after the attack are criticised and their reasons for joining and remaining are questioned $(20 / 06 / 95 ; 17 / 04 / 18)$. Another common enquiry is why well-educated young people were drawn to the movement $(20 / 06 / 95 ; 30 / 11 / 11 ; 23 / 06 / 12 b ; 20 / 03 / 18 ; 17 / 04 / 18)$. The answers can only and should be retrieved from the believers themselves $(20 / 03 / 18)$. In addition to their responsibility, the character of the members is also discussed. One author refers to them as “fanatic believers" (狂信的信者; 31/10/99a). Another writer asserts that "there is nothing more pathetic than a young man that has been guided by an idiotic leader” (愚かな指導者に導かれた青年ほど哀れなものは ない; 09/03/04) describing an encounter they had with an Aum member in their hometown. Letter authors see a bad attitude among members (specifically Asahara's eldest daughter) that can be observed when listening to their words (16/07/96). However, the opposite notion is also represented in the letters. One author is wondering whether one of their acquaintances, who had never been a bad person and had joined Aum, was also a “victim" (犠牲者; 31/03/13) of the group. Others also believe that Aum members might actually be good people who found themselves tangled up in a delinquent movement (15/12/99). This sentiment was expressed very drastically in one letter, asserting that “Aum believers aren’t aliens” (オウムの信徒はエイリアンで はありません; 12/07/02).

The group's founder is discussed less in the letters. For the most part, authors criticise his behaviour during public hearings and trials, either making absurd claims about how a vision-impaired individual could not commit the crimes he was tried for $(18 / 05 / 95 b)$, or not answering questions at all and even falling asleep (18/01/05). His pleading not guilty is therefore not deemed to be his authentic belief: "Does he himself really believe in his innocence?”(本当に本人が無罪を信じているのだろうか; 06/11/03). There is agreement that Asahara—his birth name is Matsumoto Chizuo 松 本智津夫; when the trial began authors gradually started to refer to him only by this name, therefore disregarding his religious persona-masterminded and delegated Aum’s crimes; consequently, he “has to decidedly atone” (しつかりと償うべきである; 09/03/04) for it. 
In contrast to the founder and the adult members of Aum, the members' children are almost unanimously positively viewed. ${ }^{13}$ They are mostly discussed in relation to communities and schools rejecting their families and/or them. Authors repeatedly stress that the children did not choose to join Aum but their parents made the decision. Similarly, the children are not to be blamed for their parents' crimes and should not be punished for what adult members did (03/04/00; 20/11/00; 30/03/04; 23/09/06). One author condemns the assumption that Aum's members' children would necessarily show the same negative behaviour as their parents as "letting prejudice escalate" (偏見をエスカレートさせる; 19/03/04). The letters criticise schools and communities that reject the children and express their right to receive an education, which is also an important element of their re-integration into society $(03 / 04 / 00 ; 28 / 07 / 00$; $20 / 11 / 00 ; 19 / 03 / 04)$. However, as one writer suggests, in order to make them achieve their full potential, they need to be separated from the bad influence of the Aum members and supervised by “right-minded third parties” (良識ある第三者; 12/02/00a). When discussing the Aum children, there is a lot of emotion and concern involved. One contributor writes that their “heart hurts”(心を痛めずにはいられません; 03/04/00) when thinking of what the children are going through. Another author “becomes concerned” (不安になる; 28/07/00) not knowing how the children will be treated at the next place they move to. One writer who took care of some of the members' children for a while before they returned to their families "becomes happy" (う れしくなる; 08/06/99) when hearing they are doing well.

\section{Society}

The contributions dealing with society can be divided into three subgroups: 1) letters discussing how a deficient aspect of society caused Aum - especially its young members - to be formed and commit violence; 2) criticism of the way society copes with the aftermath of the affair; and 3 ) ideas and suggestions about what society needs to move forward successfully.

The aspects of Japanese society that are highlighted as having contributed to the rise of Aum are no different from those that are widely criticised in other contexts. Whereas one contributor thinks that “Japan as a whole is sick” (日本全体が病んで いる; 22/04/95), others restricted the causes to more defined areas. Some identify being stuck in the powerful economic and political systems of ever-urbanising landscapes that take a toll on the present social situation (03/05/95), creating "individuals who have lost a place to go" (行き場を失った人間; 23/05/95b) and “a society in which human connections weaken” (人と人の結び付きが希薄になっている社会; 27/05/95) as the problem. The young people of Japan are without much social support,

\footnotetext{
13 The exception is one contributor's aforementioned criticism of Asahara's eldest daughter's attitude.
} 
having nobody to talk to (15/06/95), which caused some of them to join Aum, since “there are people who listen to you” (話を聞いてくれる人がいる; 31/05/95). One author expanded this problem to struggling women and mothers who were attracted to Aum as well (08/06/99). Many others turn to a critique of the educational system. With education being overvalued, young people are stuck in an “exam war” (受験戦 争; 13/05/95), pushing aside other important aspects of life. One contributor asserts that school drains children, claiming that "their expressions become hard once they enter elementary school” (小学校に人ったとたんに表情が硬くなる; 23/05/95a). Focusing on the sole accumulation of knowledge causes students to "not see the bigger picture” (全体像が見えない; 05/06/95), thus creating a lack of “sensible citizenship” (良識ある市民性; 05/06/95). One writer compares this “absolute obedience towards authority” (権威への絶対服従; 07/01/97) as reminiscent of World War II. The affair shows how “important it is to keep questioning” (疑問を持ち続けることが大事であ ると; 23/11/95).

Regarding the handling of the situation by Japanese society, letter authors also put forth various criticisms. Here too a concentration on Japanese youth can be observed. For example, a letter claims that young people do not know Buddhism enough to not be deceived by Aum (23/05/95c). Another contributor looks worriedly at what they perceive to be "lethargy" (無気力; 05/01/97), but at the same time lauds the social commitment they see in many young people volunteering in charity work. On the other hand, tendencies to take World War II or the Aum affair too lightly are also detected (29/04/98). A second focal point is society's treatment of suspects and former members. This is exemplified in the case of the previously mentioned and falsely suspected Kōno Yoshiyuki, who was a victim of "verbal and physical harassment and pressure” (有形無形の嫌がらせや圧力; 22/06/95a). Further points of contention are cases of vigilantism (31/10/99b), aggressive treatment of suspects (17/05/01), and the societal rejection of former members (22/08/00) - the latter being a clear sign of a poor “sense of the constitution" (憲法感; 12/07/02). The rejection of the children of Aum members by schools is criticised and their right to go to school is defended, since they “did not become members by their own will” (自分の意思で信徒になったわけ でもなく; 24/09/95), and it is necessary to show to these children "the way of justice" (正義の道; 08/03/00). Years later, authors lament that the rejection continues when some of the founder's children are not allowed to enrol at the university, because of the "prejudice that if the parents are like that, the children must be the same” (親がこ うだから、子どももこうだといら偏見; 19/03/04).

In a similar vein, letter authors suggest that people need to learn from the Aum affair in order to improve and move forward towards a better future for Japanese society. Whereas one author advocates for philosophy as a means to improve society through the “incessant activity of reason” (絶え間ない理性の活動; 18/05/95a), and another contributor calls for "compassion" (共苦; 20/05/95a) as the foundation for peace, many letters stress the urgent need to learn from the Aum affair. This ranges 
from “having to continue telling the story” (語り継いでいかねば; 06/02/14), further watching Aum's follow-up groups, and "continuing to learn" even into the Reiwa era (学んでいく; 14/07/18). What society needs is action from those who advocate for it (04/07/99b); under no circumstances should Japan become hostile towards "migrants and minorities" (移民やマイノリティー; 17/11/15). A contributor believes “there is no way but to trample down the scars by walking on the right path” (正しい道を行くこと で、その傷痕を踏み固めるしかない; 12/07/18b).

\section{Law}

Discussions in this category revolve around four different laws: the Religious Corporations Law (Shūkyō hōjin-hō 宗教法人法); the Anti-Subversive Activities Law (Hakai katsudo bōshi-hō 破壊活動防止法; short Habō-hō 破防法); the death penalty; and changes to the law in connection with the United Nations Convention against Transnational Organised Crime (kokusai soshiki hanzai bōshi jōyaku 国際組織犯罪 防止条約, among other abbreviations). In the last case, contributors concentrated on the fact that they could not recognise how the convention could have prevented the Aum attack, as argued by the government (23/02/17; 18/05/17; 15/06/17).

Soon after the subway attack, readers argued that the legal reactions to the situation were too slow, since Aum had not yet been stripped off the status as religious corporation, and “an enactment of special legislation is taking too long” (特別立法の制定 も遅すぎる; 28/03/95b) speaking from the point of the Matsumoto attack one year earlier. Some contributors, highlighting "how much many Japanese are supported by religion” (宗教によってどれほど多くの日本人が支えられている; 15/12/95), argue against a change to the laws to limit freedom for religious bodies, or at least call for “a careful and calm discussion” (慎重かつ冷静な議論; 23/09/95). Another author considers a revision of the law “a danger” (危険である; 08/09/95a) to religious freedom. Others, however, support a stricter Religious Corporations Law, especially concerning tax relief: "religious corporations cannot be sanctuaries or under extraterritorial law” (宗教法人も聖域や治外法権ではあり得ない; 29/09/95) by “being given favourable treatment under tax law” (税法上、有利な処遇が与えられている; 27/10/95a). One contributor thinks that the criteria for tax relief are not "always applied properly," an issue that Japan should “address vigorously” (メスを入れる; 07/07/10).

The second law that was heavily discussed in connection to Aum is the aforementioned Anti-Subversive Activities Law. One letter author expressed disappointment at a perceived lack of publicly available expert opinions on the application of the act to Aum. The letter refers to a questionnaire sent out by the Asahi Shinbun to legal experts about this issue, but the response rate was extremely low, and the author's "expectations were betrayed" (期待は裏切られた; 28/09/96). Other contributors had already come to their own conclusions regarding the act. Some supported the application to 
Aum, arguing that the movement was not a religion, but "no more than a terrorist group” (テロ集団にすぎず; 19/12/95b). Reservations were voiced mainly in regard to the procedure itself, being afraid that a poor execution of necessary steps to its application might “lead to increased resistance” (抵抗感をみすみす増大させる; 21/01/96b) towards the act or "lead to a non-applicability" (不適用に結びつく; 21/01/96a) of it. The majority, however, opposed the application of the act to Aum, considering it a “dangerous idea” (危険な発想; 17/12/95). Contributors were worried there might be a "high chance of a violation of basic human rights" (基本的人権を侵 す可能性が高く; 18/12/95). One author puts it rather peculiarly, when they imagine that Japan might turn into a "fighting democracy" just "like in Germany, where neoNazi groups are not recognised”(ドイツでネオナチの結社が認められないように; $19 / 12 / 95$ c) — alluding to a future need to undemocratically fight groups that oppose democracy. Others anticipate that the application to Aum "could become a precedent" (前例となってしまう), which would be lamentable, considering they understand the act as an unconstitutionality (憲法違反; 24/01/96). Given these points of contention, one author explicitly rejects the act, asserting that "this law should not exist in a democratic state that upholds basic human rights” (基本的人権の保障された民主主義国 家にあつてはならない法律である; 08/02/97).

Lastly, the death penalty was discussed as the Aum trials were coming to a close. There is no clear tendency for or against it in the corpus. Few contributors were unsure whether to reject or support capital punishment, doubting it is appropriate to sentence members who executed the leadership's orders, comparing their situation to that of the Japanese army during war (03/11/98) or being unsure about their stance towards criminals “being killed by the state power”(国家権力によつて人の命が絶たれる; 04/03/13). Clear supporters argued that the severity of Aum's crimes justify it as "one of the few cases that demonstrates the sense to continue the death penalty" (死刑制 度を存続させる意味のあることを示す、数少ないケースの一つだ; 12/07/18a). Other authors urge the responsible minister not to delay the death penalties that were already decided (02/12/11b), or argue for the maximum penalty for the usage of biological weapons to be extended from lifelong prison sentences to the death penalty $(23 / 10 / 01)$. Another contributor thinks there should be a difference made between the leadership and the followers, in the sense that “accomplices should not be executed first" (従犯 の刑が先に執行されてはいけない; 11/10/08). Critics of the death penalty, on the other hand, do not agree that the severity of a crime justifies the execution of the criminal since “every human life was given from heaven” (すべての人間の命は天 から与えられた; 05/08/97). As someone who lost their child in a car accident, they do not believe that the death of the perpetrator could alleviate negative thoughts and emotions $(31 / 05 / 98)$. In addition to the risk of wrongly convicting and executing innocent people (16/12/99), one of the authors compares the killing of criminals to the murders committed by Aum, pointing out what they perceive to be arbitrary justifications for 
killing human beings through time and space, for example in the case of the death penalty or war $(01 / 03 / 04)$.

These discussions show that even though the Aum incident was an extremely emotional affair that affected many people in Japan, contributors remained largely sceptical towards legal changes and some even questioned the established institution of the death penalty, even for Aum members.

\section{Politics}

Throughout the corpus, no positive statements are made in regard to politics or its actors. The letters are used as a medium to publicly voice one's concerns and criticisms. The ways Aum and the political realm were connected are diverse. A common topic is the opinion that politics, or more precisely the government, are not reacting to the Aum incident in a satisfying way. In the earliest letters after the attack, authors stated that the government's “reaction is too slow” (対応が遅すぎる; 28/03/95b), or that its "problem solving abilities are low" (問題解決能力が低下; 13/07/95). Perceived disagreement or lack of effective communication between politicians caused contributors to "feel strong apprehensions in regards to a law revision in this confused state” (混乱した状態の中での法改正には強い危惧を感じる; 17/10/95). On the other hand, there is also the evaluation that the government was rather unproductive, asserting that crises like the Aum incident "are no excuse for letting the Diet come to a halt” (国会をストップさせる理由にはならない; 02/12/95b). This alleged passivity also comes into play when a contributor expresses their disconcertment that national institutions seemed to unknowingly have used software provided by none other than Aum (or a sub-company thereof). The author expresses concern that the group may have had access to sensitive data, and calls for institutions to "properly guard the nation’s classified information” (国の機密をしつかりガードする; 11/03/00). Other letters suggest the use of Aum as a rhetorical device. For example, one reader interprets law revisions concerning Aum as one step to the "transformation to a military state" (軍事大国化; 11/10/01). In a more recent letter, a reader questions the connection between the prevention of terrorist attacks and the ““conspiracy” bill” (「共謀罪」法 案; 15/06/17) discussed under the Abe administration. The terror attacks in France on November 13, 2015, prompted one reader to ask "I wonder what Japan's terrorism countermeasures look like?” (日本のテロ対策は、どうなのだろうか; 17/11/15), alluding that the reduction of trash cans in train stations following the Aum attack might not be sufficient. Another interesting point is the criticism regarding the death penalty. Whereas one author thought justice minister Hiraoka Hideo 平岡秀夫 (b. 1954) as being too "passive" (消極的; 02/12/11b) when it came to ordering executions, seven years later when orders were given by justice minister Kamikawa Yōko 上川陽子 (b. 1953), two contributors complained about the minister's casual attitude towards the 
issue, since photos of her smiling at a celebration the evening of the same day were published (13/07/18; 15/07/18).

Several articles focused on the Social Democratic Party of Japan (Nippon Shakaitō 日本社会党) and its then-leader and prime minister Murayama Tomi'ichi 村山富 市 (b. 1924; in office 1994-1996) in connection to the application of the Anti-Subversive Activities Law. Given that the party opposed the law when it was first issued, readers feel like Murayama was "trying to nullify the achievements left behind by his predecessors” (先輩の残した成果をご破算にしようとしている; 03/10/95). It should be known by members what the party “fought against with all they had” (身を挺して 反対した; 17/12/95), that is, be aware of the political history and values of their party. Contributors did not see the "“people-friendly politics" (「人にやさしい政治」; 27/12/95) Murayama promised when he took the office of prime minister. Another letter author considers the application of the act to Aum as one of the many poor responses by the government that show that it "should not be judged by 'quantity,' but “quality”” (「数」ではなく、「質」によって評価されるべきだ; 09/01/96).

A last interesting point is that criticised politicians were compared to Aum at a handful of occasions. Concerning the handling of historically problematic relationships to other Asian nations, a contributor sensed the distrust of neighbouring countries and asked: “Isn’t the Japanese government the Aum of today?" (日本政府は今の才 ウムではないか; 07/06/95). A few years later, then-prime minister Koizumi Jun'ichirō's 小泉純一郎 (b. 1942; in office 2001-2006) positive attitude towards the Yasukuni shrine (Yasukuni jinja 靖国神社) was viewed similarly. ${ }^{14}$ A reader recognised the same "lack of empathy" (他者感覚のなさ; 10/06/05) in him that they witnessed in the pre-war era and in Aum. Giving “superficial” (表面; 22/05/00) answers to questions inspired the comparison of then-prime minister Mori Yoshirō 森喜朗 (b. 1937; in office 2000-2001) with Joyū Fumihiro, the then head of Aum follow-up group Aleph. Another author was reminded of the concept of Asahara as a charismatic leader of Aum in the face of the then-governor of Tōkyō who was popular even though he made “self-centred, problematic statements” (自己満足的問題発言; 31/10/99a). This shows that not only are political actors viewed critically in letters, but some regard them as bad enough to draw a comparison with the violent group Aum.

\section{Media}

Letter authors rarely express anything other than criticism when discussing the media and, similarly, they do not have many expectations regarding the media outlets - and if they do, they are mostly located within the context of critique. In one letter, the wish

\footnotetext{
${ }^{14}$ Among the deceased enshrined at Yasukuni are Class-A war criminals; thus, the shrine is often seen as a symbol for Japanese militarism and visits by Japanese government officials have inspired criticism in and outside of Japan (Takenaka 2015: 2).
} 
for thorough research and news coverage on the Aum case to be conducted by the media independently from the police is expressed along with criticism of the police $(20 / 05 / 95 b)$. Another letter author, who is a concerned parent, would like to see the media find answers to the questions why Aum was so attractive to young people and what went wrong with it (23/05/95d). The last instance of a reader voicing their expectations towards the media can be found in a letter addressing the TBS incident, articulating how they want all media (and not just TBS) to reflect on their attitudes that are at the root of the scandal (29/03/96).

The TBS Aum incident as it is referred to in some letters (TBS no Ömu jiken TB Sのオウム事件 [03/07/96]; “TBS to Ōmu” no jiken「TBSとオウム」の事件 [14/04/96]), is the topic of a large number of letters concerned with the media. Even before the said incident, the Tōkyō Broadcasting Network was viewed critically for using the aforementioned subliminal techniques (サブリミナル手法; 14/06/95). But when the news surfaced that TBS showed members of Aum an interview about the group with the lawyer Sakamoto Tsutsumi 坂本堤 (1956-1989), who founded the aforementioned Aum Shinrikyō Higaisha no Kai, and that TBS did not broadcast the interview following protests from Aum, criticism took off. Especially condemned are the network's silence about the matter-not only after Sakamoto disappeared $(27 / 03 / 96)$ but long after the subway attack (23/03/96b) - and the one-sided showing of material to Aum (28/03/96). Some authors believe that further incidents, and even the Tōkyō attack, could have been prevented had TBS handled their knowledge of Aum's conduct more responsibly and thus supported the investigations (23/03/96a; $23 / 03 / 96 b)$. Writers suspect that TBS kept the matter to itself in order to not harm its own reputation, initially claiming “no memory” (記憶にない; 28/03/96) of any of it. A number of authors believe that such attitude by the media outlets played a role in the unfolding of the events, since the journalists seemed to be "afraid to be sued by Aum” (オウムから訴えられるのを恐れる; 29/03/96). ${ }^{15}$ Only one contributor argues that the consumers of media also have responsibility in the overall problem in the media that culminated in the TBS case. They lament that most consumers of news do not question anything that is broadcast to them, and that "if the audience does not change, the characteristics of programmes that reach high ratings will not change either, thus making it possible for a similar incident to occur in the future" $(23 / 04 / 96) .{ }^{16}$ Similarly, a former journalist suspects contemporary media production circumstances to be one contributing factor of the problem (14/04/96). Other letter authors view the issue as a moral problem on the production side, pointing at the media's double stand-

\footnotetext{
${ }^{15}$ Aum was notorious for its fights against the media before the Tōkyō attack as outlined in the introductory sections.

16 視聴者側が変わらなければ、視聴率最優先の番組作りの体質は変わらないだろうし、また同じ ことがいつか起こるだろう。
} 
ards by comparing the outlet's conduct to that of the Ministry of Health that was criticised by TBS in the wake of the HIV blood scandal (22/03/96; 23/03/96a; $23 / 03 / 96 \mathrm{~b}) .{ }^{17}$ Hence, the incident is often regarded as a symptom of moral shortcomings, either a complete "lack of morals" (モラルの欠如; 27/03/96), or as a problem of the “TV station staff”s ego" (テレビ局スタッフのエゴ; 29/03/96).

One of the letters summarises many contributors' thoughts on the subject by listing several questions directed towards the TBS journalists that were involved in the case, of which a portion is quoted below.

Do you not think that if you didn't show [Aum, P.S.M.] the video [of Sakamoto, P.S.M.], he and his family would not have been targeted? The family was considered missing; why did you not report your own conduct even when there was a call for the collecting of information? Do you not think that many innocent people would not have been killed and that the Matsumoto and subway sarin attacks, from which many people still suffer aftereffects, would not have occurred if this [the TBS incident, P.S.M.] had become a clue and Aum would have been investigated earlier? $(11 / 04 / 96) .{ }^{18}$

Apart from the TBS incident, the media are criticised for treating suspects as culprits before having been convicted by a court (27/04/95), harassing Aum members' relatives $(22 / 05 / 95)$, erroneous news reports $(25 / 12 / 96)$, and in general too much coverage of the Aum case that “makes the audience go crazy” (視聴者の頭もおかしくなる; 28/04/96). Even outside the TBS case, letter authors are not content with the media's handling of Aum. There is no understanding for the sensationalism that is employed regarding the group; for example, by having an “actor” (タレント; 03/07/95) re-enact the death of an Aum member during training, or by adding overly dramatic voiceovers and ominous music. Another author states that "TV news should be done calmly" (テレビの報道は冷静に行うべきだ; 05/03/04). A contributor whose family business was damaged after being shown on TV together with an Aum facility, and thus being wrongly associated with the group by many viewers, criticises the media's attitude when they sense the “journalists' selfishness” (報道陣の身勝手さ; 21/06/95a) in their entering the author's father's shop simply to take photographs of the said Aum facility.

\footnotetext{
${ }^{17}$ The HIV blood scandal (yakugai eizu jiken 薬害エイズ事件) was an affair involving HIV-contaminated donor blood that infected a large number of haemophilia patients in Japan in the 1980s. It sparked a wave of public criticism and distrust of the Ministry of Health, which did not acknowledge a haemophiliac displaying symptoms of AIDS as the first case of HIV in Japan, and failed to warn other haemophilia patients that they may have been infected as well. In a court case, 1,800 HIVinfected haemophilia patients received compensations of forty-five million Yen (approx. US\$ 375,000) each (Feldman 1999: 60, 63-64).

18 もし、ビデオを見せなければ、坂本弁護士一家は狙われずに済んだとは思いませんか? 一家 が失跡したとされ、情報の収集を呼びかけておきながら、なぜ、自らの行為を通報しなかったの ですか?もし、それが糸口となって、オウムにもつと早く捜査が入っていれば、何の罪もない多く の人が殺され、後遺症に苦しむことになる松本・地下鉄サリン事件も起きなかったのではないかと 思いませんか?
} 
Another instance of wrongful association of unrelated individuals with Aum that is mentioned in the letters is the media's treatment of Panawave, as briefly outlined in the introduction. One author likens the coverage of the group to a "modern witch-hunt" (現代の魔女狩り; 09/05/03), whereas another indicates that the media irritate Panawave's members to no avail and commit a "violation of their rights to their own pictures” (肖像権の侵害; 08/05/03). The members should be protected legally $(09 / 05 / 03)$.

\section{Education}

The topic of education is discussed in the corpus in two ways: either concerning the Japanese education system or the right to education of former Aum-members (or children of members). Attempting to make sense of the fact that many highly educated individuals committed crimes in the name of Aum, the letter authors suspect that the flawed education system has played a significant role, for example, by stating that school education is one "root" (根; 22/04/95) of the Aum issue. Education seems to be concentrating only on “accumulating knowledge" (知識を積み上げる; 22/04/95) and the training of "specialised skills" (高度な技術; 26/05/95), for example, those in biology and medicine (20/06/95) in the case of medical students, causing the alumni to become nothing but "specialised idiots" (専門バカ; 21/02/97). The authors lament the lack of "humanity" (人間性; 22/04/95; 21/02/97; 09/04/00) in the content and nature of Japanese education facilities that have become mere "diploma issuing machineries" (卒業証書発行機関; 23/06/95b). They then advocate for the incorporation of "ethical values" (倫理観; 19/05/95) into the curriculum, making sure to not only foster knowledge but also the ability to make use of it in a manner that ensures contribution to society $(29 / 07 / 18)$.

Besides the criticism of the education system, contributors nevertheless stress the importance of integrating Aum-members' children and even re-integrating former members of the group into it. Letter authors worry about the dubious "future of the children” (子供たちの未来; 04/02/00) due to communities and schools rejecting them, and “former members' societal rehabilitation being hindered" (元信者の社会復帰の 障害; 11/04/02). It is considered their “right to learn” (学ぶ権利; 11/04/02), and authors expect teachers to have the "courage" (勇気; 06/04/02; 06/03/06) to accept and give them guidance in order to "not let them tread on the wrong path" (間違つた道に 踏み入らせない; 02/07/99) in life, reminding the readers that the children are "not involved in the crimes” (犯罪にはかかわっていません; 04/05/04). One contributor argues for the necessity of the children to "cut ties with the religious group" (教団と 縁を切る; 12/02/00a) and therefore their families, in order to ensure the school education to bear fruit. 


\section{Executive}

Apart from some writers expecting executive forces to solve the crimes surrounding Aum, most statements concerning such forces consist of criticisms of various kinds. Whereas one letter laments that information given regarding backgrounds and motives is "close to none" (皆無に等しく;20/05/95b), another thinks it is necessary to increase the number of police officers (14/07/95b). The police's conduct receives strongly negative evaluations in several instances. The treatment of Kōno Yoshiyuki as a suspect in the Matsumoto sarin attack "without proper evidence” (証拠らしい証拠もないま ま; 19/09/95) is used to question the police's “attitude" (姿勢; 22/06/95a). All the while being “weak when confronted with strong opponents” (「力」のあるものに弱い; 19/09/95), the police was dealing strictly with Kōno since he was not a powerful person. While arrests because of minor offences are not necessary (14/07/95a), the sending away of a fugitive who turned himself in at a police station was also met with the demand for the police to "overthink its handling of unsolved cases" (未解決事件 への対応を見直すべきだ; 11/01/12). Several contributors pointed out the executive's shortcomings when dealing with internal issues, like a "sloppy response" (ずさ んな対応; 03/11/96) to learning that a police officer had been a member of Aum, or having “unknowingly used software developed by Aum” (オウム製のコンピューター ソフトとは知らずに使用していた; 11/03/00). Two authors expressed feelings of discomfort—one of them even "fear" (恐怖; 23/06/12a) — when thinking of being captured by surveillance cameras, which played an essential role in the tracking down of one fugitive. In the case of a plane hijacking on June 21, 1995, which was believed at first to have been perpetrated by a member of Aum, but who turned out to have been a copycat, one author criticised how long it took the police to resolve the case, calling its handling of the incident “completely like that of children” (まるで子供並み; 27/06/95). In response to this, another letter defended the authorities' careful proceedings, having "arrested the culprit merely wounded with all passengers and staff safe" (乗客、乗員の命が無事で、かつ、犯人もケガだけで逮捕することができた; 30/06/95).

\section{Religion}

One of the least discussed topics in the letters is religion in general, suggesting that it is not of central importance to letter writers in connection to Aum. Authors' views regarding the matter are rather mixed. Whereas some writers assume a positive nature or ideal of religion, for example, "preaching people's paths and saving their hearts" (人の道を説き人の心を救うこと; 28/03/95a), “being something that becomes one’s strength to live and creates hope and courage for the future” (生きる力となり、未来へ の希望と勇気を創出するもの; 30/11/11), or “having made the happiness of people its goal” (人の幸福を目的としていること; 27/10/95a), many use this notion to point 
out what is missing in religion in their eyes. The author who penned the first quoted letter, for example, states that he has "long before felt suspicion and distrust towards religion and especially some new religious movements” (宗教、とりわけ新興宗教と いわれる教団の一部に以前からうさん臭さと不信感を持っていた; 28/03/95a) and that, not only with Aum, "troubles with members and money as well as joining them and withdrawing from them” (信者とカネ、入信と脱会に関するトラブル; 28/03/95a) always follow religious groups. Another contributor argues that even before Aum, religious groups "have caused the disruption of many families, trials, and inconvenience and damage to society” (家庭破壊や裁判ざたを多発させ、社会に迷惑や損 害をかけた; 21/10/95). The involvement of religion in politics is also discussed adversely, one author explicitly claiming that "when it is connected to politics, it also has a violent side that leads believers to the persecution and killing of non-believers" (政治などが関係すると、異教徒の迫害、虐殺へと信者を駆り立てる狂暴な面も持 つている; 29/05/00). Another letter laments a collective view in politics that political activities by religious groups are constitutionally acceptable (02/12/95a). An author is unhappy with religious groups' response to the incident, asking "what have established religions done?” (既成の宗教は何をしていたのか; 11/07/99). Another contributor criticises religious groups voicing the feeling that their religious freedom is or could be threatened by political reactions to the Aum affair; they assert that "religious freedom means individuals' freedom of thought, and is not there for groups to evade societal scrutiny" $(15 / 09 / 95) .{ }^{19}$

Letter authors expect of religious groups to re-evaluate themselves (28/03/95a), and to honestly and openly confront their own past mistakes, since "all religion is being doubted due to the Aum incident” (オウム事件で宗教全体が疑問視されてい る; 16/06/95b). Religion and, more specifically, established religious groups and actors have “the responsibility to improve the quality of religion” (宗教の質を高める 責任, 04/04/95), “taking pride in contributing to society” (社会に貢献するといら自 負を持って; 04/04/95).

In one letter, religious groups are explicitly lauded by an author recounting how their alcoholic mother was supported by members of a religious group for a long time, until she recovered. For this individual, it is important to remember that "many people in Japan are supported" (多くの日本人が支えられている; 15/12/95) by religion. Authors with an official religious position are keen on stressing that religion is benevolent and beneficial, explaining how a focus on supernatural powers that do not help other people "is not Buddhism” (仏教ではない; 23/05/95c), nor is it about “becoming a slave of the founder" (教主の奴隷になる; 23/05/95c), which implies what they see in Aum. A pastor thinks that they see the true role of religion in people who muster

19 信教の自由とは、個人の精神的自由の一つであって、宗教団体が社会の監査を逃れる自由 ではあるまい 
up their trust and come to temples or churches to ask for help in difficult life situations $(20 / 03 / 02)$.

\section{Trials}

Lastly, some letters discussed issues relating to the Aum trials. Most deal with critique or apprehensions. For example, the length of criminal trials in Japan was questioned even before the Aum trials started. In this context, the Aum case was seen as a "chance" (チャンス; 16/06/95a) to improve this issue. Further down the road, writers criticised the time it took to come up with a verdict in Asahara's case, asking "why does it take so long?” (なぜそんなに時間がかかるのだろうか: 06/11/03). Other points of critique are that the trial was not publicly accessible enough, and that the appointment of a state-selected lawyer was not necessary considering the existence of privately appointed defence. One writer criticises the religious clothing of Asahara, since "the courtroom is not a place for religious proselytisation” (法廷は、宗教の宣伝の場で はありません; 27/04/96). The defence's court techniques were also questioned, suspecting that their main objective was prolonging the entire process. After the trials had come to a close, writers lamented that the questions of why and how young, welleducated people could have been lured by the group were not answered, with one contributor writing that "the High Court should have put more effort into that matter" (高裁にはもう一工夫あるべきだった; 31/03/06).

Such critique is also congruent with the expectations and fears letter authors voiced regarding the trials. They wished they would progress fast, offer answers to people's questions, uncover yet unsolved incidents, and for the defence to not hamper the advancing of the trial and neglect "social justice" (社会正義; 18/09/96) for the sake of their client.

While writers were not happy with the length of the Aum trials, one contributor writes that the intended length of trials under the lay judge system would be way too short for a complex matter like the Aum case. Another author lauds the High Court's overturning of a guilty sentence in a lay judge Aum trial on the basis of "in dubio pro reo”(疑わしきは罰せず; 03/12/15).

\section{Conclusion}

As outlined in the introductory remarks, scholars were largely critical of Aum coverage in the media (Isomae 2014: 122). Shimada Hiromi articulated this view concisely, claiming that, whereas the mass media cared about sensationalist stories to boost their ratings, scholars tried to find out what about Japanese society caused the group to be so extremely critical — or even hostile — towards it. Many scholars of Japanese religion 
reiterated this view. For Helen Hardacre (2003: 142-144), there exists a taboo on positive reporting on Japanese NRMs, preventing consumers of media from constructing anything other than a negative image of these groups in their minds. Martin Repp (1997: 62) senses the causes of the Aum affair in society as well, which means that a state that combats Aum only fights the symptoms rather than the causes. The media, in contrast, contributed nothing much other than conjuring up hysteria (ibid.: 68).

Contributors of letters to the editor from 1995 to 2018 largely did not join in on the hysteria Repp observed in media coverage. Instead, as shown in the analysis, they themselves strongly criticised the media for their attitude towards the Aum affair and the group itself. Furthermore, letter authors used their voices to actively search for or at least pose the question of what caused (young) people to join Aum and subsequently use violence in the name of the group. They presented some theories to answer this question: some saw the problem in the Japanese educational system, others in an impersonal, modern lifestyle. Furthermore, they actively engaged with politics', courts', and police's responses to the issue, voicing criticism. Readers refrained from characterising Aum as enemies alone by advocating for showing compassion to the children of members. Overall, it can be said that letter authors engaged with the issue and its manifold manifestations in a rather reflected manner. This can be further illustrated by comparing the topic categories to scholarly publications on the subject.

Repp's (1997) monograph engages with the questions of what aspects of Japanese society factored into the development of Aum and why especially young individuals seemed to be drawn to the group, and critically examines how society coped with the aftermath of Aum and the subway attack. As shown in the analysis, this is very similar to the way letter authors discussed Japanese society in their texts.

In the introduction to their edited volume Religion and Social Crisis in Japan (2001), Robert Kisala and Mark Mullins outline the book's content and focus, arguing that "one can understand more about [...] Japanese society by considering the various reactions and responses to [...] the 'Aum affair' by representative groups and institutions in Japanese society" (Kisala and Mullins 2001: 4). Considering the topics examined in the letters, this is precisely what the letter authors seem to have attempted to do in their writings. A look at the contents of the edited volume in question reveals that many of the key themes discussed in the letters can also be found in the collected scholarly articles: for example, police and other security authorities (Hughes 2001), law and politics (Mullins 2001), and mass media (Gardner 2001). However, letter authors also engaged critically with other topics, like education and religion in general.

Beginning in 1995, the year of the subway attack, the Religious Awareness Project ( “Shūkyō ishiki chōsa” purojekuto「宗教意識調査」プロジェクト) of the Japanese Association for the Study of Religion and Society ( “Shūkyō to shakai” gakkai 「宗教と 社会」学会) conducted surveys every year up to 2017 (“Shūkyō to shakai” gakkai 2020) among university students (ranging somewhere between four to eleven thousand respondents), enquiring into their attitudes towards religion. Taking into account 
the results of the survey from 1995 to 2000, Robert Kisala summarises the respondents' views as follows: approximately $7 \%$ believe in any religion, whereas around $70 \%$ do not see a necessity for religion. However, only $3 \%$ have attested to have had negative experiences with religion themselves. Kisala interprets this discrepancy as being at least partly influenced by public discourses of the time (Kisala 2006: 5). Of course, the group examined by this survey consists of young people in higher education, and thus is not representative of the entire population of Japan. However, as shown above, the demographics of the letter authors in the present sample largely belong to higher educated population groups, and therefore the views in the survey may be more representative of the authors in the corpus than the overall Japanese population.

The daily newspaper Yomiuri Shinbun conducted a similar survey in 1995 with a less restricted focus group, giving the respondents multiple choices as to what is their opinion about religion. $40 \%$ of participants thought that religions care mainly about making money, 37\% were sure religious groups actively take advantage of people's fears. A few respondents felt like religion was too strongly involved with politics (20\%), and 18\% "that religion was "only for show", (Kisala 2006: 5).

Many of the views expressed by respondents to the Yomiuri Shinbun survey can be found in the examined letters as well. Aum itself is unanimously viewed negatively. Apart from the children of members, contributors do not have anything positive to say about the group, so much so that some argue the follow-up groups that constituted themselves after the Aum affair should be closely observed. Concerning religion in general, the picture is more complex. Overall, the topic was not of great importance in the corpus, being among the two least discussed subjects; apparently religion was not the main interest of people engaging with the Aum issue. Many letter authors are critical of religion in general, arguing that even before the emergence of Aum, religious groups had repeatedly caused problems in Japan, whereas some authors focus on the response to the Aum affair by religious groups. As a consequence of many contributors calling Aum a false religion, some letters explain how religion should ideally be beneficial for society. It is important to note that some of the letter authors claiming that real religion is a good force in society, and Aum therefore illegitimate, are themselves religious experts; one author is the chief priest of a Buddhist temple 住職 (32/05/95c) and another is a pastor 牧師 (20/03/02).

This last case clearly illustrates why Bruce Lincoln stresses the following questions as important in the study of religious discourse: "What is accomplished by classifying something as 'religion'? By whom and for what purpose? Who is for it, and who is against it?" (Lincoln 2012: 5; cf. Taira 2016: 131). Naturally, religious stakeholders are eager to exclude Aum from the category of religion, but they are not the only ones in the corpus who consider true religion to be generally benevolent. Concerning the discursive study of religion, Kocku von Stuckrad points to "tacit knowledge," which is not explicitly discussed or questioned, but implicitly assumed to be self-evident by actors in a given discourse - of course, this varies from context 
to context (von Stuckrad 2013: 9-10). Manuel Alexander Simon (2019: 117) takes up this concept in his analysis of discourse of religion in the context of the 2016 presidential election in Austria, and gives the example that, often times, an inherent "goodness" of religion is assumed, whereas examples that do not conform with this are placed somewhere outside of religion. Eileen Barker likewise stresses this mechanism, writing that the concept of bad religions

implies the contemporaneous existence of 'good' and 'true' religion as something to be protected and clearly differentiated from bad or false religions, which, in order to avoid confusion, can be denied the label religion and, in the popular parlance of the day, branded as cults [...] (Barker 2011: 198).

This, however, does not seem to apply to most letters to the editor in this context. Whereas it has been shown that most contributors (roughly 57\%) do not care to engage with the question of whether Aum is a religion or not, the majority of those who do define Aum as a religion (roughly 34\%), rather than using terms like cult or brainwashing, or regarding the group a false religion (roughly 9\%), are critical of religion itself. This agrees with the results of the Religious Awareness Project survey.

Thus, it can be said that letters to the editor of Asahi Shinbun in the Heisei era regarding Aum Shinrikyō care less about discussing religion than engaging with and critiquing perceived failures of the system and societal weaknesses that led to the affair, and the subsequent handling of it by authorities as well as society as a whole.

\section{ABBREVIATIONS}

AFF

ICSA

NRM

TBS

\author{
American Family Foundation \\ International Cultic Studies Association \\ New Religious Movement \\ Tokyo Broadcasting System
}

\section{REFERENCES}

Astley, Trevor. 2006. "New Religions.” In Paul L. Swanson and Clark Chilson, eds., Nanzan Guide to Japanese Religions. Honolulu: University of Hawai'i Press, pp. 91-114.

Baffelli, Erica. 2016. Media and New Religions in Japan. New York: Routledge.

Baffelli, Erica. 2018. “Aum Shinrikyō.” In Lukas Pokorny and Franz Winter, eds., Handbook of East Asian New Religious Movements. Leiden and Boston: Brill, pp. 193-210.

Barker, Eileen. 1995. "The Scientific Study of Religion? You Must Be Joking!” Journal for the Scientific Study of Religion, 34 (3), pp. 287-310.

Barker, Eileen. 2011. "The Cult as a Social Problem.” In Titus Hjelm, ed., Religion and Social Problems. New York: Routledge, pp. 198-212. 
Dorman, Benjamin. 2005. "Sheets, Seals and Sensation: Pana Wave and the Media." Asian Studies Review, 29 (1), pp. 19-34.

Feldman, Eric A. 1999. "HIV and Blood in Japan: Transforming Private Conflict into Public Scandal." In Eric A. Feldman and Ronald Bayer, eds., Blood Feuds: AIDS, Blood, and the Politics of Medical Disaster. New York: Oxford University Press, pp. 59-93.

Gardner, Richard A. 2001. "Aum and the Media: Lost in the Cosmos and the Need to Know." In Robert J. Kisala and Mark R. Mullins, eds., Religion and Social Crisis in Japan: Understanding Japanese Society through the Aum Affair. Basingstoke: Palgrave Macmillan, pp. 133-162.

Hardacre, Helen. 2003. “After Aum: Religion and Civil Society in Japan.” In Frank J. Schwartz and Susan J. Pharr, eds., The State of Civil Society in Japan. Cambridge: Cambridge University Press, pp. 135-153.

Hardacre, Helen. 2007. "Aum Shinrikyô and the Japanese Media: The Pied Piper Meets the Lamb of God." History of Religions, 47 (2/3), pp. 171-204.

Hassan, Sutībun スティーブン・ハッサン . 1993. Maindo kontorōru no kyōfu マインドコントロールの 恐怖 [The Fear of Mind Control]. Tōkyō 東京: Kōyū shuppan 恒友出版.

Hughes, Christopher W. 2001. "The Reaction of the Police and Security Authorities to Aum Shinrikyō.” In Robert J. Kisala and Mark R. Mullins, eds., Religion and Social Crisis in Japan: Understanding Japanese Society through the Aum Affair. Basingstoke: Palgrave Macmillan, pp. 53-69.

ICSA. 2021. “About Us.” Online: https://www.icsahome.com/aboutus (accessed: April 21, 2021).

Introvigne, Massimo. 2000. The Unification Church. Salt Lake City: Signature Books.

Isomae, Jun'ichi. 2014. Religious Discourse in Modern Japan: Religion, State, and Shintō. Leiden and Boston: Brill.

J-town.net. 2018. “Heisei o daihyō suru 'dai nyūsu' to ieba? (Sayonara Heisei ankēto) 平成を代表 する「大ニュース」といえば?【さよなら平成アンケート】[When Asked about the 'Big News' that Represent Heisei? (Goodbye, Heisei Poll)].” Online: https://j-town.net/tokyo/research/votes/269539.html (accessed: July 4, 2019).

Keishichō 警視庁 Metropolitan Police Department. 2016. “Ankēto kekka dai 1 i kara 10 i made ア ンケート結果 第 1 位から 10 位まで [Poll Results from Number 1 to 10].” Online: https://www.keishicho.metro.tokyo.jp/smph/about_mpd/welcome/welcome/rank_top/ rank1_10.html (accessed: July 4, 2019).

Kisala, Robert. 2006. “Japanese Religions.” In Paul L. Swanson and Clark Chilson, eds., Nanzan Guide to Japanese Religions. Honolulu: University of Hawai'i Press, pp. 3-13.

Kisala, Robert J. and Mark R. Mullins. 2001. "Introduction.” In Robert J. Kisala and Mark R. Mullins, eds., Religion and Social Crisis in Japan: Understanding Japanese Society through the Aum Affair. Basingstoke: Palgrave Macmillan, pp. 1-17.

Kōkoku Asahi 広告朝日. 2021. “Data File 2021: Asahi Shinbun Baitai Shiryō Data File 2021 朝 日新聞媒体資料 [Data File 2021: Data for the Medium Asahi Shinbun].” Online: https://adv.asahi.com/adv/other/ad_info/media_kit/DataFile2021.pdf (accessed: April 21, 2021).

Lincoln, Bruce. 2012. Gods and Demons, Priests and Scholars: Critical Explorations in the History of Religions. Chicago: The University of Chicago Press.

Mayring, Philipp. 2015. Qualitative Inhaltsanalyse: Grundlagen und Techniken. Weinheim: Beltz. McLaughlin, Levi. 2012. "Did Aum Change Everything? What Soka Gakkai Before, During, and After the Aum Shinrikyō Affair Tells Us about the Persistent 'Otherness' of New Religions in Japan.” Japanese Journal of Religious Studies, 39, pp. 51-75. 
Mullins, Mark R. 2001. "The Legal and Political Fallout of the 'Aum Affair'.” In Robert J. Kisala and Mark R. Mullins, eds., Religion and Social Crisis in Japan: Understanding Japanese Society through the Aum Affair. Basingstoke: Palgrave Macmillan, pp. 71-86.

Nifty News nifty ニュース. 2019. "Heisei furikaeri (jiken - saigai) ni tsuite ankēto rankingu 平成 振り返り(事件・災害)についてのアンケート・ランキング [Heisei Recap (Incidents and Catastrophes) Poll Results].” Online: http://chosa.nifty.com/season/chosa_report_A20190301/? theme $=$ A20190301\& the-me=A20190301 (accessed: June 11, 2019).

Pokorny, Lukas. 2018. “Unification Movement”. In Lukas Pokorny and Franz Winter, eds., Handbook of East Asian New Religious Movements. Leiden and Boston: Brill, pp. 321-342.

Reader, Ian. 1996. A Poisonous Cocktail? Aum Shinrikyō's Path to Violence. Copenhagen: NIAS Press.

Repp, Martin. 1997. Aum Shinrikyo: Ein Kapitel krimineller Religionsgeschichte. Marburg: Diagonal-Verlag.

Rosu, J. C. and M. D. Rangōni J・C・ロス、M・D・ランゴーニ. 1995. Karuto kyōdan kara waga ko o mamoru hōカルト教団からわが子を守る法 [How to Protect Our Children From Cults]. Tōkyō 東京: Asahi Shinbunsha 朝日新聞社.

Sakurai, Yoshihide 櫻井義秀. 2002. “'Shūkyō higai” to jinken/jikokettei o meguru mondai: Tōitsu kyōkai kanren no saiban o chūshin ni『宗教被害』と人権・自己決定をめぐる問題

一統一教会関連の裁判を中心に一 ['Religious Damage' and Issues Related To Human Rights and Self-Determination: At the Centre of Trials Related to the Unification Church]”. Gendai Shakaigaku Kenkyu 現代社会学研究 (Contemporary Sociological Studies), 15, pp. 63-81.

Shioya, Yūichi 塩谷祐一. 2017. "Midashi ya nenrei, shokugyō. Kanshin o motta kōtō kara "choi yomi’ o 見出しや年齢、職業。関心を持った投稿から「ちょい読み」を [Headline, Age, Occupation. Have a "Short Reading" from Contributions that Sparked Your Interest]." Online: https://info.asahi.com/choiyomi/reporter/koe/ (accessed: February 12, 2020).

“Shūkyō to shakai” gakkai「宗教と社会」学会. 2020. “Purojekuto no shōkai プロジェクトの紹介 [Introducing Our Projects].” Online: http://jasrs.org/projects/project.html (accessed: January $18,2021)$.

Simon, Manuel Alexander. 2019. "Politics or Religion? The Discursive Negotiation on Publicly Effective Categories in the 2016 Austrian Federal Presidential Election.” In Lukas Pokorny and Hans Gerald Hödl, eds., Religion in Austria, Volume 4. Wien: Praesens, pp. 115-160.

Taira, Teemu. 2016. 'Discourse on 'Religion' in Organizing Social Practices: Theoretical and Practical Considerations.” In Frans Wijsen and Kocku von Stuckrad, eds., Making Religion: Theory and Practice in the Discursive Study of Religion. Leiden and Boston: Brill, pp. 125146.

Takenaka, Akiko. 2015. Yasukuni Shrine: History, Memory, and Japan's Unending Postwar. Honolulu: University of Hawai'i Press.

von Stuckrad, Kocku. 2013. "Discursive Study of Religion: Approaches, Definitions, Implications." Method \& Theory in the Study of Religion, 25, pp. 5-25.

Wahl-Jorgensen, Karin. 2002. "Understanding the Conditions for Public Discourse: Four Rules for Selecting Letters to the Editor." Journalism Studies, 3 (1), pp. 69-81.

Wahl-Jorgensen, Karin. 2007. Journalists and the Public: Newsroom Culture, Letters to the Editor and Democracy. Creskill, NJ: Hampton Press. Online: https://www.academia.edu/522902/ Wahl-Jorgensen_K._2007_.JJournalists_and the_public_Newsroom_culture_letters_to the_editor_and_democracy._Creskill_NJ_Hampton_Press (accessed: November 5, 2019).

Watanabe, Manabu. 1997. "Reactions to the Aum Affair: The Rise of the 'Anti-cult' Movement in Japan." Nanzan Bulletin, 21, pp. 32-48. 
Wilkinson, Gregory. 2009. "The next Aum: Religious Violence and New Religious Movements in Twenty-first Century Japan." Ph.D. Thesis, University of Iowa, USA.

Winter, Franz. 2018. "Japanese New Religious Movements: An Introduction.” In Lukas Pokorny and Franz Winter, eds., Handbook of East Asian New Religious Movements. Leiden and Boston: Brill, pp. 17-32.

Yoshida, Reiji and Murakami Sakura. 2018. "Aum Shinrikyo Guru Shoko Asahara and Six Other Cult Members Hanged for Mass Murders.” The Japan Times, July 8. Online: https://www.japantimes.co.jp/news/2018/07/06/national/crime-legal/aum-shinrikyo-gurushoko-asahara-hanged-mass-murder-reports/\#.XkACl25Fw2w (accessed: February 9, 2020). 